\title{
The American West's longest large mammal migration: clarifying and securing the common interest
}

\author{
David N. Cherney · Susan G. Clark
}

Published online: 8 May 2008

(C) Springer Science+Business Media, LLC. 2008

\begin{abstract}
Over the last 10 years, conflict has grown over a 170-mile pronghorn antelope (Antilocapra americana) migration between Grand Teton National Park and the Upper Green River Basin in western Wyoming. Resolving conflict in the common interest is proving difficult. This movement is the longest mammal migration in the lower 48 states, spanning the jurisdiction of three federal agencies, three Wyoming counties, and over 40 private landowners. In addition, there are over ten non-governmental conservation organizations, two major state agencies, Wyoming's executive office, and many citizens involved in the issue. There are three major problem definitions serving the beliefs of participants: the ecological-scientific (conservation biologists, environmentalists), local rights (local control, property rights), and cultural value (historic, western heritage) definitions. These definitions challenge the social and decision making processes of regional communities and government agencies. Underlying the problem of securing the common interest is the highly fragmented patterns of authority and control, misorganized arena(s), and parochial perspectives of many participants. Options promoted by participants can be loosely classified as top-down (government, expert driven) versus bottom-up (local, practice-based) approaches and reflect preferences for the distribution and uses of power and other values. Given the social and decision making context of this case, the bottom-up, practiced-based approach would likely best secure a common interest outcome.
\end{abstract}

Keywords Policy process appraisal · Common interest · Problem definition · Conflict · Wildlife management and policy · Practice-based approach ·

Wildlife migration · Transboundry management

\footnotetext{
D. N. Cherney $(\bowtie)$

Center for Science and Technology Policy Research, University of Colorado at Boulder, 1333 Grandview Avenue, Campus Box 488, Boulder, CO 80309-0488, USA

e-mail: david.cherney@colorado.edu

S. G. Clark

Yale School of Forestry and Environmental Studies, 301 Prospect Street, 2nd Floor, New Haven, CT 06511, USA

e-mail: susan.g.clark@yale.edu
} 


\section{Introduction}

The American West has many natural resource management challenges highly resistant to resolution in the public interest. Among these are large mammal conservation conflicts, especially federally listed carnivores (e.g., grizzly bears; Ursus arctos horriblis) and long distance migratory species (e.g., elk; Cervus canadensis) (Clark et al. 2005). Cases are complex for contextual reasons, including numerous agencies and citizens involved, public-private land interfaces, and high symbolism of species and their ecology (Clark and Rutherford 2005). One such case is the pronghorn antelope herd that summers in Grand Teton National Park and migrates over 170-miles south through the Upper Green River Basin to lands north of Rock Springs, Wyoming. How to manage this herd is highly politicized with no imminent resolution in the common interest (e.g., Huntington 2003; Robbins 2004; Jalonick 2005).

This paper describes and analyzes the management policy process of this migration and recommends ways forward. To date, biological aspects of the migration have received the most attention (e.g., Harper 1985, Unpublished; Segerstrom 1997, Unpublished; Sawyer and Lindzey 2000; Berger 2004a). Researchers at the National Park Service, Wildlife Conservation Society, and Wyoming Game and Fish Department continue to develop ecological knowledge. Our study complements this work by focusing on social, political, and decision-making factors at the heart of the conflict. Understanding ecological factors allows managers to make technical decisions. Understanding decision-making conditions allows people to realistically target management and policy changes that secure shared interests, once these are clarified through democratic means.

Information was gathered from three sources between 2004 and 2006, and the case was followed more generally to date. First, we conducted a literature review of scientific articles, management plans, environmental impact statements, local and national periodicals, technical reports, websites, organizational promotional material, and other relevant sources. Second, during summer 2004, we spent 94 days traveling in the migration corridor talking with people who were involved or interested in the pronghorn migration. We conducted follow-up interviews and site visits in summers of 2005 and 2006 and continued to track the literature. We conducted over 80 semi-structured interviews and open-ended discussions with participants from the Bureau of Land Management (BLM), energy industry, environmental community, local and state government, private landowners, ranching community, United States Forest Service (USFS), National Park Service (NPS), scientific community, and Wyoming Game and Fish Department (WGF). And third, we attended 21 public meetings held by the BLM, Jackson Hole Chamber of Commerce, Jackson Hole Conservation Alliance, Pinedale Town Council, Questar Inc., Shell Petroleum, Sublette County Commission, Sublette Planning and Zoning, Wildlife Conservation Society, and WGF. This empirical data serves as basis for our description, analysis, and recommendations. We use quotes from interviewees but keep sources anonymous where respondents wished to remain unknown publicly.

Our research was guided by a genuinely interdisciplinary problem solving approach and analytic framework described by Lasswell and McDougal (1992). This central-theory is about people and society and focuses on how problems are oriented to by individuals and groups, how people interact, and how the decision making process actually works. It is beyond the scope of this paper to describe this research approach in detail. Our approach is often described as a problem oriented, contextual, multi-method set of conceptual tools that can be used empirically to understand any case and find practical recommendations to improve decision outcomes (Lasswell 1971; Clark et al. 2000; Clark 2002). 


\section{Migration management}

Pronghorn restoration in Wyoming is one of the most successful wildlife stories in the American West over the last century. Prior to 1850s, more than a million lived in Wyoming and 50 million existed in the western United States (Einarsen 1948). By 1900, industriallevel hunting reduced numbers to near extinction. Wyoming's pronghorn population was 2,000 by 1912 (Bell 1954). The state, in 1909, enacted legislation to temporarily ban hunting (Thomas 1966). Today there are approximately 450,000 pronghorn in Wyoming, a 225-fold increase since 1912 (WGF 2003). This success story resulted in the adoption of pronghorn as part of the Wyoming Game and Fish Department's emblem and one of Wyoming's most prominent wildlife symbols.

Pronghorn antelope are the only endemic ungulate (hoofed mammal) to North America (O'Gara and Janis 2004). As a result, pronghorn evolved with a different set of predators than other North American ungulates (e.g., elk, deer). This accounts for the species' unique traits, especially their top running speed of 60 miles per hour and an endurance speed of 30 miles per hour (Byers 2003). Speed, in combination with their exceptional eyesight, is their primary defense mechanism against predators (Lubinski 2001).

Many of Wyoming's pronghorn migrate, but none travel as far as the 170-mile migratory herd (Berger et al. 2006). The few hundred pronghorn that make this migration are considered part of a larger management unit called the Sublette Antelope Herd of approximately 45,000 animals. Whereas it is difficult to make "hard and fast distinctions between migrations and other movement behaviors," migrations are the regular (often seasonal) movements of an organism between two distinct areas of habitat (Dingle 1996, p. 39). Berger (2004b) claims that this pronghorn migration is the second longest land mammal migration in the Western Hemisphere to the caribou (Rangifer tarandus) migrations of Alaska and the Yukon. Archeological data shows that at least a portion of the Wyoming pronghorn migration occurred 6,000 years ago (Miller and Saunders 2000).

Pronghorn were historically present in Grand Teton National Park. While a few pronghorn have attempted to winter in the region over the years, pronghorn are considered seasonal residents (Berger 1991). Deep snow conditions force animals to leave the Park and find more suitable winter habitat in areas south (Harper 1985, Unpublished). Whereas other migration routes may have existed in the past, migration through the Upper Green is the only one used today. In short, this migration prevents local extinction of pronghorn in Grand Teton National Park (Berger 2003).

There are four areas along the migration corridor that physically narrow to distance less than a few hundred yards wide (Berger 2004a). There is concern by some individuals that housing and natural gas development in and near the narrow portions, commonly referred to as "bottlenecks," will eliminate movement by physically plugging the migration route, just as a cork plugs a wine bottle. The most well known instance of such an event occurred in 1983 when several hundred migrating pronghorn died as the result of newly erected fence and deep snow conditions in another area in Wyoming (Johnson 1988). Additionally, there is unease among conservationists that natural gas development in the more expansive southern areas of the migration may cause harmful indirect effects, such as behavioral changes or decreased population numbers that may disrupt the pronghorn migration. Historically, this migration was halted in the early 1900s, likely due to the low population numbers from over hunting. In the 1950s, WGF observed the migration's reestablishment on its own (Straley 1966; Harper 1985, Unpublished). 
Defining the problem

What makes the potential disruption of this migration a problem? Who is it a problem for and why? To some people, the answers are obvious. To these individuals, this migration is seen as an opportunity to help save "the last of the great long-distance migrations" (Berger 2004 b, p. 22). People with this perspective see migration as "nothing short of a miracle," and question if "we really want to be the responsible party for bringing this wildly majestic act of grace to a screeching stop?" (Dale 2004, p. 5A). To other people, the answer is not clear. At a public meeting in Pinedale, WY, one resident questioned, "If we have 500,000 antelope in Wyoming, what difference does a few hundred make?" (Interview, anonymous representative A of the Sublette County Commission, 2004). Clearly there are differing views of the "problem." Diverse, contradictory points of view exist.

Understanding participants and their perspectives is not simple. There are many actors. The migration spans jurisdictions of three federal agencies (Grand Teton National Park, Bridger-Teton National Forest, Bureau of Land Management Pinedale), three Wyoming counties (Teton, Sublette, and Sweetwater), and over 40 private landowners. There are over ten conservation non-governmental organizations, two major state agencies, Wyoming's governors' office, and a number of local and national private citizens all active in the decision process focused on the migration. To gain insight, we identified participants' "problem definitions" as advanced in their own words.

The construction of problem definitions is a social endeavor. Problems do not exist in nature, "out there," independent of human interpretation. They are the product of people's values, beliefs, and expectations. Problems are discrepancies between a person's goals and the current trends or projected likely state of affairs (Lasswell 1971). Because different people have different goals and see the future differently, they hold different problem definitions. Problem definitions "implies a certain set of values and goals on the part of the individual," even for scientists who presume themselves to be neutral and objective (Brewer and de Leon 1983, p. 35). Problem definitions yield insight to how an individual views "the causes and consequence of undesirable circumstances and...how to improve them" (Weiss 1989, p. 97). We identified three clusters of competing problem definitions: "ecological-scientific, the local rights, and cultural value."

The ecological-scientific definition

This definition emphasizes biological features and the presumed intrinsic value of the migration. It can be summarized as follows: the disruption of this migration will cause (1) localized extinction of pronghorn in Grand Teton National Park, and (2) loss of the longest land mammal migration in the lower 48 states. These projected outcomes are unacceptable, and thus the migration itself automatically necessitates protection. This definition implies that a major goal of migration management is to maintain the movement of pronghorn between Grand Teton National Park, the Upper Green, and areas further south. There is an expectation that without more active, formal protection of the migration the herd survival is unlikely. For most proponents of this definition, protection requires government intervention from the federal level.

People who use this definition tend to identify strongly with "scientific management" (Brunner et al. 2005). There is a general attitude that people who do not support this problem definition are ill-informed, misguided, or malevolent. One conservation community member stated that this migration, "is an unrecognized essential element to this 
region," and that people who disagree with her version of protection "tend to only see bits and pieces of what is occurring, and do not understand the big picture" (Interview, anonymous representative of a wildlife conservation organization, 2004). She continued that, "the best way to change how decisions are made in the region is through education," referring to teaching people how to "correctly" interpret positivistic derived biological facts. Such statements imply an expectation that people who do not hold her worldview will be swayed if presented with the "right" scientific information, often enough, and persuasively.

Proponents of this problem definition demand greater protection, often in the form of federal government intervention. An employee of the Greater Yellowstone Coalition explained that finding a workable solution in this case, "is really a job for the government" (interview, anonymous representative of Greater Yellowstone Coalition, 2004). In general, participants understand "government intervention" as the establishment of a formally designated migration corridor (i.e., a "national migration law"). For example, a representative for the Wildlife Conservation Society suggested at the Wind River Institute for Journalism \& Natural Resources in Pinedale, WY (June 11, 2005) that protection could range from the designation of the migratory corridor as an extension of Grand Teton National Park to a less formal designation, similar to Scenic Byways.

Proponents see such a designation as a would-be victory with huge implications for conservation nationally and internationally. Establishing a migration corridor would be a first of its kind in the United States. A resident of Teton County described any successful campaign for protection as a victory for "ecosystem management" (Interview, anonymous environmental donor, 2005). To her, it would symbolize recognition "that the movement of wildlife between protected areas is important." In other words, formally designated protection would serve to reinforce the held worldview (values, beliefs, and expectations) of people who hold this problem definition.

\section{The local rights definition}

This definition was developed in reaction to the ecological-scientific perspective's demands. The local rights definition claims that western Wyoming has many large mammal migrations. The loss of a few hundred antelope is not cause for real concern. The real problem is the environmental groups trying to force their agenda on private citizens by "locking up" public and private lands from productive economic use. This definition focuses on individual and private property rights. There is an expectation that a formally designated migration corridor, as proposed by some people, would infringe on these rights.

People who adhere to this problem definition identify strongly with the historical culture of the region. These individuals "take pride in making a living from the land," and view wildlife as a secondary concern (Taylor and Clark 2005, p. 33). The previous quote by a Pinedale rancher, "if we have 500,000 antelope in Wyoming, what difference does a few hundred make," illustrates this point. To this third generation rancher, the migration serves little practical purpose. A follow-up interview revealed that he highly values Wyoming's pronghorn population for human enjoyment, and thinks that the WGF is effectively managing the population (Interview, anonymous representative A of the Sublette County Commission, 2004). He does not see the need to spend additional resources on protecting one small antelope herd.

People using this problem definition have a status quo strategy on management. A Sublette County Commissioner stated that, "when you look at the whole area it is one big 
migration route" (Interview, anonymous representative B of the Sublette County Commission, 2004). This individual holds an expectation that, "[the] pronghorn have always migrated and they always will." A natural gas worker said that, "we see pronghorn on the [Pinedale] anticline [an area along the migration route with high density natural gas development] all the time" (Interview, anonymous natural gas worker, 2004). He believes natural gas development impact on pronghorn is overstated by the environmental community.

For proponents of this definition, the issue has less to do with the pronghorn migration and more to do with what they view as loss of "respect" for themselves. A rancher from Daniel, WY explained, "It is ranching that has kept this land open. So, ranching and wildlife are not a contradiction...I don't understand why these people come here and try to tell us what to do" (Interview, anonymous rancher from Daniel, WY, 2004). Another local resident said, "We won't stand for widespread environmental destruction. I know it is a cliché, but us cattlemen need to be good environmental stewards to survive.... Without good stewardship we would go out of business." (Interview, anonymous resident from Pinedale, WY, 2004) To him, the implication that this migration needs protection is an attack on him personally, by outsiders, who doubt his skill and stewardship ethic.

\section{The cultural value definition}

This definition, although it is an independent, stand-alone definition, is often partially incorporated into both the other two definitions. Whereas there is much common ground among them, there are distinct differences. The cultural value definition holds that this migration is part of the cultural heritage of western Wyoming, and that it would be a shame to lose the migration. The definition argues that we should do what we can, without impinging significantly on our other values, to maintain this migration. As in the ecological definition, one of the major goals is to maintain the pronghorn migration. There is an implied concern that the migration may be lost, but the definition lacks the ecologicalscientific demand for government intervention. It suggests that Wyoming people should make all decisions, that more science is not needed, and certainly no federal intervention is warranted.

The proponents share a similar identity often with supporters of the local rights problem definition. However, these individuals appear to have a deeper affinity for wildlife. A member of the Upper Green Cattlemen Association reflects, "I have known about this migration [for years] and enjoyed it as a child, adult, and old-man.... I hope my children will be able to enjoy the migration as I have" (Interview, anonymous representative of the Upper Green Cattlemen Association, 2004). This individual spoke of how he and his wife annually drive to Trapper's Point National Monument-a narrow portion of the migration corridor - to specifically watch migrating pronghorn. A WGF representative explained that "pronghorn serve as an icon for Wyoming," and are an important part of the local culture (Interview, anonymous representative A of Wyoming Game and Fish Department, 2004).

This definition focuses on maintaining the local character of rural Wyoming. It sees the migrations of wildlife as important aspect of local people's identity, but it must be balanced against their other values within the local context. In reference to a "government" versus a "local" solution, a state representative asserted that, "sometimes we run out and get a baseball bat when all we needed was a fly swatter" (as cited in Jalonick 2005, p. A10). Proponents of this definition demand a solution of "gentle persuasion" versus "formalized protection." A WGF representative noted, "We are concerned about the migration, but 
cannot force everyone to do what we want" (Interview, anonymous representative B of Wyoming Game and Fish Department, 2005). He explained the best way to move forward is to work with individual landowners on changing land management practices that will benefit the migration with little economic impact. An employee of Pinedale's Department of Planning and Zoning said that in Wyoming "you can't just tell people what to do....you need to work with them" (Interview, anonymous representative of Pinedale Planning and Zoning, 2004).

\section{Migration politics}

The three competing problem definitions are by no means a fully comprehensive account of all ways participants frame the migration issue. However, the definitions illustrate that the people involved have diverse worldviews and seek different alternative outcomes. To achieve their desired outcomes, participants are forced to mutually engage each other in a process of continual bargaining. This determines who gets what, when and how or what we conventionally refer to as politics (Lasswell 1936). We can understand this process by analyzing the situations in which social interactions and decision-making occurs. This includes the processes of collecting, processing, and disseminating information, debating alternatives, formalizing plans of action, implementing those plans, appraising efforts, and adapting as circumstances change. For this migration, interaction among participants has been primarily carried out in two situations: environmental advocacy and agency planning.

\section{Environmental advocacy}

Regional and national conservation advocacy groups largely initiated the current migration's policy process via “educational campaigns." A Wyoming Outdoor Council (WOC) participant asserts that raised awareness of the pronghorn migration surfaced in 1999 following a number of meetings in Wyoming addressing the Jackson Hole National Elk Refuge Environmental Impact Statement (see Clark et al. 2000 for background). She recalls a meeting that focused on the migratory patterns of elk, which in turn provoked discussion on what other large mammals migrated near Jackson Hole, WY. Discussions "woke up" the environmental community to the fact "we have the longest migration, south of the Yukon, in our backyard" (Interview, anonymous environmentalist, 2004).

The environmental community quickly rallied around two aspects of this migration. First was protection of the migration corridor. Whereas there initially appeared to be no immediate threat to continuation of migration, an employee of the Jackson Hole Conservation Alliance (JHA) asserted that this migration provided an opportunity for the conservation community to be "proactive and raise awareness [of wildlife movements]" (Interview, anonymous representative of the Jackson Hole Conservation Alliance, 2004). Conservation groups such as the JHA, Greater Yellowstone Coalition, Sierra Club, Wildlife Conservation Society, WOC, Upper Green River Valley Coalition, Wilderness Society, have worked, and continue to work, both individually and collectively to create public support for corridor protection. Their advocacy has largely taken the form of public presentations, publication of promotional material, and opinion pieces in the news media.

Development of the idea for protecting the migration was initially based on the concept of protecting wildlife movements for connectivity in general, which is a larger conservation theme in the region. The idea was given more life through programs such as the WOC's Restoring Wild Patterns. A major purpose of this and allied programs was to use 
this migration as a flagship for conservation of wildlife movements everywhere. As the Wildlife Conservation Society, a wildlife science and conservation organization, began conducting biological research on this migration, the focus of the conservation community shifted from generalized protection of mammal migrations to a focus on the specific pronghorn case and its connection to a national park (Berger 2003; Berger et al. 2006). The focus was also on the presumed inherent value of protecting the longest migration in the lower 48 as a model for conservation elsewhere (Berger 2004a). These ideas, promoted through scientific management, served to ground and legitimize protection in the eyes of the conservation community.

Importantly, this pronghorn movement has also been used by the environmental community as a vehicle to oppose natural gas development along the migration corridor. In the past decade, southwestern Wyoming has seen a huge increase in natural gas development and production. There are approximately 8,500 developed natural gas wells in southwest Wyoming today, with a projected increase of 10,000 to 15,000 more during the next 10 years (Thomson et al. 2005). These wells are estimated to produce over $\$ 30$ billion of revenue in next 75 years (Loftholm and McGuire 2006). The development of natural gas has been extremely controversial, leading to lawsuits and separate advocacy campaigns by conservation and citizen's groups. Despite such lawsuits, the interest groups attempting to curb development have largely been unsuccessful in stopping development. The issue of the migration has become a central focus and tool for some members of the conservation community in their opposition to further development. They use the pronghorn migration issue to fight development by attempting to generate sympathy for the animals and by pitting the migrating pronghorn against the natural gas industry, as in a David and Goliath story (e.g., Williams 2004).

Advocating for protection of the migration and reduced natural gas development has much in parallel. In both advocacy situations, the environmental NGO community crafted a message to convince other participants to support their ecological-scientific definition's preferred alternative. However, all the advocacy work appears to have minimal impact on formal decision making to date. In fact, there has been a backlash by people who subscribe to the local rights problem definition. As declared by the editor of a regional newspaper, “The environmental groups' sudden concern about preserving wildlife corridors and bottlenecks in Sublette County is more about raising money than saving deer and antelope herds" (Shaul 2003, p. A4). He continued, "The environmental groups aren't dumb. They knew they needed a better argument to fight oil and gas development and found the wildlife corridor issue" (Ibid.).

\section{Agency planning}

The majority of open public discussion, regarding the migration, occurs through formal forums created for government agency planning. These are often public meeting or solicitations for written statements through mandated requirements of the National Environmental Policy Act (NEPA). Typically, an agency develops a draft plan or impact statement, and then requests the public to comment on the document. The agency compiles comments and integrates them in planning as the agency judges appropriate. The majority of discussion regarding the migration has occurred in four planning efforts: the BLM's Pinedale Region Resource Management Plan, the Pinedale Anticline Environmental Impact Statement, Johan Infill Project Environmental Impact Statement, and the BridgerTeton National Forest's Forest Plan Revision. However, the migration was most heavily 
discussed in the planning process for the BLM Pinedale's Resource Management Plan revision.

Bureau of Land Management Pinedale's Resource Management Plan revision provides guidance "for managing over 900,000 acres of federal surface estate lands and over 1.1 million acres of federal mineral estate lands in Sublette, Lincoln, and Fremont Counties, Wyoming," which includes a significant portion of the pronghorn migration (BLM 2005). The BLM held three meetings in March 2003, where it became clear that the migration was a significant topic of concern to the public. However, in the view of many participants, the three 5-h meetings did not provide an adequate forum for discussion of the migration.

At the prompting of Shell Oil, a state representative founded a working group to address natural gas development at a contentious area along the migration route called Trapper's Point National Monument. The representative was interested in creating a forum where "productive dialog" could help by "identify points of concern" shared by all interests (interview, anonymous state representative, 2004). He invited representatives of the diverse interests, including the natural gas industry, BLM, Sublette County Commissioners, the environmental community, Sublette Planning and Zoning, the Governor's office, Wyoming Department of Transportation, and WGD.

The Trapper's Point Working Group, as it was called, hoped to create a consensus-based agreement to recommend to the BLM for its Resource Management Plan. Four meetings were held between October 1 and December 8, 2003. At the fourth meeting, the BLM stated that an agreement must be submitted to the agency within four days to be incorporated into the plan. The December 8 meeting nearly ended in consensus, but the groups failed to come to a final agreement in the end. On December 14, the representative who convened the working group sent a letter to the BLM with a proposal that he felt was compatible with the sentiments of working group members. The environmental groups were outraged, and six days later sent another letter to the BLM clarifying their position. They stated, "no agreement has been reached....[and] all Working Group participants were caught off guard by learning we had 4 days to hash out the details of a very complex issue" (Darin et al. 2003, p. 2). In February 2007, over 3 years later, the draft BLM plan was released to the public.

\section{Challenges in decision making}

With such diverse participants in the process, over a large geographic area, finding common ground is a formidable task. Additionally, functional problems exist in the way participants interact. Though some people believe the common interest to be an unattainable ideal, it is often realizable in practice (see Brunner et al. 2002, 2005). The chief obstacle is often the process of participant interaction and decision-making, not the perceived conflicting views (Ascher and Healy 1990). It is crucial to recognize that the common interest is an ongoing effort to find solutions that work for the broad community, and that the common interest is not a single optimal solution. It is easiest to think of the common interest as a range of potential policy alternatives that may work for a community in a given place and time.

The continuing conflict over this migration indicates that participants are not attaining an outcome they collectively want. Understanding why this is so can be explained by at least three factors: (1) an "imbalance/disconnect" in the relationship between authority and control, (2) lack of adequate arenas for participant interaction, and (3) inflexibility in 
participant perspectives. The imbalance/disconnect of authority and control allows participants to shirk responsibility for managing the migration in a sustainable manner. The lack of appropriate arenas to address the real conflict creates a situation where participants are unable to resolve the differences. Inflexible demands by participants create a situation where few alternatives are considered and prevent political compromise, or an integrative solution, from occurring.

\section{Authority and control}

Citizens typically expect that natural resource managers have both authority and control to make decisions over natural resources. This means there is widespread recognition of the manager's right to make decisions regarding the resource, and that the manger actually has the power to shape outcomes on the ground. For example, the Forest Service has authority and control over timber sales on national forests, the WGF to determine hunting quotas in Wyoming, and the U.S. National Elk Refuge to feed wintering elk. These legislated authorities create a system of responsibility and accountability. However, legislated authority does not always coincide with the actual power structure or effective control in an arena (Lasswell and Kaplan 1950, p. 133; Ellickson 1991). For example, an illegal timber harvester may cut trees, despite the Forest Service's lack of approval. Similarly, a poacher may take game, without sanction by WGF. The closer authority and control are linked, the more effective any management decision making process will be in securing the broad public interest (Reisman 1988, pp. 8-9).

Every landowner along the migration route has the ability to make land use decisions that affect pronghorn movements. For example, the BLM determines if and where industry can drill for natural gas, an activity that may displace or disturb pronghorn. Private landowners can build fences, roads, and homes that may physically block migratory animals. The Forest Service can thin conifer tree encroachment through fire or timber harvest in areas critical to the pronghorn's movement, thus opening up new movement areas. In other words, these participants can exercise significant control over the management of the migration and fate of the animals.

Importantly, in this case, there is no shared expectation by the public about how decisions will be made and with whom the responsibility lays for the migration. For example, an employee for the Greater Yellowstone Coalition stated, "to be honest, I am not quite sure who is in charge [of managing the migration]" (Interview, anonymous representative of Greater Yellowstone Coalition, 2004). This view is evident in a Grand Teton National Park resource manger statement, "we are concerned about the migration, but the real problem [natural gas development by industry] lies in Sublette County," implying that it would be inappropriate for Grand Teton National Park to take a stand on the issue (Interview, anonymous representative of Grand Teton National Park, 2004). This is a transparent attempt to deflect her agency's responsibility for the migration to another party. Whereas, citizens typically expect bureaucracies to expand their base of authority and control, shifting or deflecting of authority to another party is chronic in this case. For instance, a representative for Shell Oil countered the park manager's statement with, "since when is an energy corporation responsible for managing wildlife!" (Interview, anonymous representative of Shell Oil, 2004). He indicated that the WGF is the responsible agency. However, a WGF official protested saying, "We manage for population numbers, not specific antelope movements" (Interview, anonymous representative A of Wyoming Game and Fish Department, 2004). Even the environmental non-profits shift 
authority to someone else, as illustrated by the previous quote from an employee of the Greater Yellowstone Coalition who said that protecting the migration "a job for the government" (Interview, anonymous representative of Greater Yellowstone Coalition, 2004).

In the meantime, the public is unsure just who has authority and control. Without clear authority over managing the migration, a "collective action" problem has developed. Many individuals and organizations are able to shape the future of the migration, but they are able to shirk responsibility for their actions. This allows each controlling participant to continue to maximize his or her special interest at the expense of finding and securing the common interest. While this is happening, threats to pronghorn migration may be growing.

Arenas

Arenas are physical places or situations in which participants are able to mutually engage each other to reconcile differences and ideally find common ground. The structure of an arena can be understood by the degree to which it is centralized or decentralized, continuous or short-lived, focusing on specialized topics or general interests, organized or unorganized, and open or closed to broad participation (McDougal et al. 1981). Whereas there is no single perfect structure for an arena (e.g., degree to which it is centralized or decentralized), an arena should "remain sufficiently flexible to balance these factors in a manner that allows the broadest community goals to be realized;" in this case, determining how decisions should be made regarding the migration (Cherney et al. 2008).

Currently, there are several arenas in which participants interact regarding the migration. For example, the NEPA process creates a situation where stakeholders can voice their interest to a federal agency. County commission and town hall meetings are places where local residents can voice their interests to elected representatives. For this migration, the primary forums of interaction have taken place through conferences, public meetings, working groups, informal discussion, public presentations, and the popular media.

We can categorize arenas that focus on the migration in at least two ways (1) peripheral arenas and (2) temporary non-authoritative arenas. Peripheral arenas are forums where the migration is not the primary focus. Rather, the migration is discussed in the context of another issue. For example, the migration is a subtopic in the BLM's planning process for natural gas development in Sublette County, WY. Whereas this may be a productive arena for the discussion of natural gas development, it limits the participant base and the geographic scope of inquiry for managing the migration. These arenas do not focus on the full migration or its context. Peripheral arenas have also been non-continuous, leading participants to reengage each other at the most basic level within each successive arena. For example, conflict over the migration has occurred in the BLM's planning process for sometime. However, the discussion of the migration in the Bridger-Teton National Forest Management Plan did not begin where the BLM's planning process left off. Participants were forced to rehash the most basic details of the migration before they could move forward with policy discussions. Such backtracking makes the issue more difficult to resolve.

Temporary non-governmental arenas are used to address a specific issue, and quickly dissipate after a single or few meetings. The Trapper's Point Working Group is an example. Others include conferences such as the Jackson Hole Wildlife Symposium, WOC's Conservation Congress, and public presentation's by environmental groups. These non-governmental arenas do complement peripheral arenas by creating a situation where a 
comprehensive view of the migration might possibly be discussed. However, temporary non-governmental arenas are lacking in at least three ways. First, similar to peripheral arenas, their temporally non-continuous nature provides brief snapshots of the problem at irregular intervals. This prevents any real dialog on management policy and its context. Second, participation is often restricted (or self-selected) to a narrow set of people-often with a mutually reinforcing worldview (e.g., mostly environmentalists or ranchers). Finally, the authority of these forums is not linked to those people and organizations with effective control. As a result, controlling officials easily ignore the plans of action developed in these arenas, such as with the Trapper's Point Working Group.

\section{Perspectives}

Individual personal factors and group identifications are also an important challenge in understanding and resolving the pronghorn migration problem. Many participants have lived in the region and interacted with each other on many other natural resource issues before. Engaging each other through multiple previous planning processes and lawsuits have created well-established adversarial roles. Some individuals in the pronghorn migration case have been involved in verbal confrontations and personal attacks amongst themselves. This has lead to some people feeling marginalized and disrespected. These kinds of interactions lead to entrenchment and distrust among the agencies, environmental, ranching, and mineral extraction communities. It makes it hard for participants to work together cooperatively and communicate effectively. At the extreme, some participants even chose not to engage those with differing worldviews. For example, one participant from the ecological-scientific definition stated "I don't see where the conflict exists. Everyone agrees with us" (Interview, anonymous grassroots conservationist, 2005). The individual continued that she did not understand why it appeared the media was making this issue appear politically polarized. Failure to even acknowledge conflicting points of view makes little room for constructive civil discourse. Without genuine communication and a willingness to work together, these groups will not be able to find common ground.

There is no doubt that most participants view pronghorn as a positive symbol for wildlife, and, all else being equal, would like to see the migration continue. From a shared interest view, narrow and absolutist demands have little legitimacy in civic dialogue. However, participants on all sides of the issue are making rigid demands with little room for compromise. For example, an environmentalist in Jackson who relies on the ecologicalscientific problem definition stated that, "a national migration corridor is the only way to achieve true protection" (Interview, anonymous representative of a wildlife conservation organization, 2004). Wyoming Representative Barbra Cubin countered with a similar absolutist demand stating there is "no chance" of a national migration corridor being established in Wyoming (Jalonick 2005, p. A10). Even a more moderate statement by the late Wyoming Senator Craig Thomas, "I think we can solve this problem locally," has been rejected by competing definitions (Ibid.). These absolutist-sounding demands feed the current gridlock.

\section{Improving the process}

There is no one right or wrong way to maintain pronghorn migration in the common interest. However, the status quo processes will likely not ensure conservation of the 
migration or resolution of the issue in the public interest. A new direction is needed. One that, at a minimum, is inclusive of the principal interests, meets the valid expectations of people, and is grounded in empirical reality (Brunner 2002). A number of different alternative courses of action have surfaced among participants. We can loosely classify the types of policy reforms being promoted as "top-down" and "bottom-up."

In conservation there is often confusion over top-down and bottom-up (or "practicebased) policy and management (Brunner and Clark 1997; Clark and Rutherford 2005). To many conservationists, top-down and bottom-up are often referred to as outcomes. The phrase "top-down management policy" connotes the creation of a new central authority (e.g., the formation of a new national park), whereas "bottom-up" means networking people who have effective power (control) over a resource (e.g., agreements between local landowners). In contrast, in the study of public policy, policy-oriented professionals and researchers are often just as concerned with the process as with outcomes. By top-down policy, professionals refer to the process by which a prescription is imposed by a central authority on a particular group of participants. In contrast, bottom-up is a process by which members of a community interact to clarify and secure their common interests by themselves. The outcomes of a new central authority or networking of participants can potentially result from either a top-down or bottom-up process. Rarely is a process fully top-down or bottom-up; a continuum always exists. Nevertheless, such a distinction is useful to aid in our understanding of alternatives.

Several participants have developed the idea for a permanent protection of the entire migration route. The concept of permanent protection for the migration follows the classic park/protected area management paradigm that we need to protect habitat and wildlife from anthropogenic effects by excluding human use. While there are no concrete formal proposals for permanent protection on the table today, the general concept is widely discussed and entails a scientifically-based plan, develop enough support to pass it through a legislative body (e.g., federal or state), and then once implemented conservation is achieved. This is the typical formula for a top-down process and from a scientific management point of view.

A successful permanently protected area must be judged not only by the final outcome of protecting species, but also by the process by which it is created. In the development of protected areas internationally, there has been much critique over reserve design-the process of creating a park. The general criticism of reserve design is that expert developed protected areas often lack contextual understanding and sensitivity to local people (Chapin 2004). This often leads to a situation whereas even though new arenas are created and authority is legislated, effective control is not always secured. In park management, this outcome is typically known as a "paper parks" or a "park in name only." These types of situations occur when the expectations of all relevant participants are not integrated effectively.

With strong law enforcement in the United States, some participants in the pronghorn migration policy process may dismiss the previous critique as irrelevant. They may argue that compliance can be forced. However, most individuals we interviewed recognized that permanent protection in the form of a new national park or protected area is not politically viable in the Wyoming context. As a result, these individuals see a fair compromise as designating the portion of the migration on U.S. Park Service and National Forest land as a "national migration corridor" in name only, and leaving the private and BLM lands undesignated. This is the equivalent of creating a "paper park." Without the ability to shape outcomes on the ground, little substantive gains will be made in securing the pronghorn migration. It will only have symbolic significance. 
Whereas significant conflict among participants exists, securing the interests of all participants is possible. Most individuals are highly motivated and personally interested in this migration. Improving migration management is not simply providing protection for the physical space that is the pronghorn movement path. Rather, it is securing a process by which conflicting interests are able to find a workable, common outcome. Solving this type of problem requires a shift in perspectives and in governance (i.e., the decision making process). The need and demand for a more productive dialog and governance process were evident in our interviews. A resident of Pinedale, Wyoming stated that, "we need to tackle the problem and not each other," a state representative from Daniel, Wyoming, said, "We stereotype each other and have skewed perceptions. We need to move beyond this," and an agency representative from Grand Teton National Park said, "If folks just engaged in conversation" (Interview, anonymous rancher from Daniel, WY, 2004; Interview, anonymous State Representative, 2004; Interview, anonymous representative of Grand Teton National Park, 2004). It is clear that people want to move to a more productive interaction.

One method to build cooperation and dialogue that has proven effective in this case is low stakes communal projects. For example, at Trapper's Point National Monument, the BLM, ranching community, environmentalists, and WGF completed a re-fencing project. These participants donated their time, equipment, and materials to covert old fences to be friendlier to wildlife movements. By sharing resources and working together on the ground, participants were able to show each other their commitment to this migration and to each other. They were able to start building trust and respect for one another through hard work, as well as improve conditions for the migrating pronghorn. As one participant remarked, "It gave us a chance to work on a common problem, and not [unproductively fight with] each other" (Interview, anonymous representative of Pinedale Planning and Zoning, 2004). Continuing this type of bottom-up approach in other places and ways is a way forward out of the current impasse.

This approach builds community, civility, and dialogue-shared authority among controlling participants from the ground up. There are many opportunities for a practicedbased approach along the entire migration corridor. The central purpose is to simply have participants see that they all care about the pronghorns and want to help maintain the movement. Such projects are a good start toward finding common ground. This process could create a system wherein participants are likely to work together to address the real issue of wildlife conservation in the public interest.

\section{Conclusion}

Participants in the management policy process of migrating pronghorn antelope between Grand Teton National Park and the Upper Green Basin, WY and the area further south, share a common concern for the animals and their free movement across large open landscapes. Despite shared interests, the process by which the participants interact creates a problematic situation wherein they are unable to find and agree on common management goals and strategies for the process itself, much less for the future of the animals. The current institutional structure, especially its formal over-organized bureaucratic arenas mixed with its informal under-organized citizen arenas serve many participants, but it does not effectively create a process through which parties can balance competing interests. The fragmented structure of authority and control over pronghorn management policy combined with the lack of effective arenas exacerbate conflict and harden the already rigid demands of participants. This has led to policy gridlock. Finding a solution that works for 
the people and interests involved is context dependent, of course. There are no generalized solutions in conservation or public policy. To move forward most productively, participants could strive to create a process that is problem oriented, contextual, and multimethod and approximates the standards of comprehensiveness, openness, reliability, timeliness, unbiased, and balanced (Lasswell 1971). Leadership will be required to bring about more fruitful participant interactions and enduring decisions. On the ground, hands-on field projects are a productive means for participants to engage each other to learn who the "other" is. It makes sense to address this process problem from a local, fully contextual way, and then multiply and scale-up successes as they occur (i.e., the practice-based approach). Ultimately, the fate of this migration lies in the hands of the local participants, but also state and federal officials. The people involved have two options. They can continue to interact and pursue their own special interests in an adversarial manner or they can try to improve the process of their own interactions and find a practical outcome in the interest of the broader community.

Acknowledgements We thank Jason Wilmot and the Northern Rockies Conservation Cooperative for their support of our research. We also thank the individuals who graciously gave up their time to discuss the pronghorn migration issue with us. Space prevents us from naming them all. This research would not have been possible without the generous financial support of the Sussman Foundation, the Carpenter-SpellenMelon Fund, LightHawk Inc., Denver Zoological Foundation, Wilburforce Foundation, Tides Foundation, and Phil and Patty Washburn.

\section{References}

Ascher, W., \& Robert, H. (1990). Natural resource policy making in developing countries. Durham, NC: Duke University Press.

Bell, R. O. (1954). Hunting in Wyoming, past and present. Wyoming Wildlife, 18, $23-26$.

Berger, J. (1991). Greater Yellowstone's native ungulates: Myths and realities. Conservation Biology, 5, 353-363.

Berger, J. (2003). Is it acceptable to let a species go extinct in a national park? Conservation Biology, 17, $1451-1454$.

Berger, J. (2004a). The last mile: How to sustain long-distance migration in mammals. Conservation Biology, 18, 320-331.

Berger, J. (2004b). Can we save the last of the great long-distance migrations? Wild Earth Fall/Winter: 22-25.

Berger, J., Cain, S. L., \& Berger, K. M. (2006). Connecting the dots: An invariant migration corridor links the Holocene to the present. Biology Letters [online edition-first cite, June 28].

Brewer, G., \& de Leon, P. (1983). Foundations of policy analysis. Homewood, IL: The Dorsey Press.

Brunner, R. (2002). Problems of governance. In R. Brunner, C. Colburn, C. Cromley, R. Klein, \& E. Olson (Eds.), Finding common ground: Governance and natural resources in the American West (pp. 1-47). New Haven, CT: Yale University Press.

Brunner, R. D., \& Clark T. W. (1997). A practice-based approach to ecosystem management. Conservation Biology, 11, 48-58.

Brunner, R., Colburn, C., Cromley, C., Klein, R., \& Olson, E (Eds.). (2002). Finding common ground: Governance and natural resources in the American West. New Haven, CT: Yale University Press.

Brunner, R., Steelman, T. A., Coe-Juell, L., Cromley, C. M., Edwards, C. M., \& Tucker, D. W. (Eds.). (2005). Adaptive governance: Integrating science, policy, and decision-making. New York, NY: Columbia University Press.

Bureau of Land Management. (2005). BLM-Pinedale resource management plan home. Available at http://www.blm.gov/rmp/wy/pinedale/index.html. Accessed on February 19, 2006.

Byers, J. A. (2003). Built for speed: A year in the life of pronghorn. Cambridge, MA: Harvard University Press.

Chapin, M. (2004). A challenge to conservationists. World Watch Nov/Dec: 17-34.

Cherney, D. N., Bond, A., \& Clark, S. G. (2008). Understanding patterns of human interactions and decision making: An initial map of Podocarpus National Park, Ecuador. Journal of Sustainable Forestry. 
Clark, T. W. (2002). The policy process: A practical guide for natural resource professionals. New Haven, CT: Yale University Press.

Clark, T. W., Casey, D., \& Halverson, A. (Eds.). (2000). Developing sustainable management policy for the national elk refuge, Wyoming. Bulletin Series: Yale School of Forestry and Environmental Studies Number 104.

Clark, T. W., \& Rutherford, M. B. (2005). The institutional system of wildlife management: Making it more effective. In T. W. Clark, D. Casey, \& A. Halverson (Eds.), Coexisting with large carnivores: Lessons from Greater Yellowstone (pp. 211-253). Washington, D.C: Island Press.

Clark, T. W., Rutherford, M. B., \& Casey, D. (Eds.). (2005). Coexisting with large carnivores: Lessons from Greater Yellowstone. Washington, D.C.: Island Press.

Clark, T. W., Willard, A. R., \& Cromley, C. M. (Eds.). (2000). Foundations of natural resources management and policy. New Haven, CT: Yale University Press.

Dale, G. Y. (2004). Antelope over houses! Pinedale Roundup May 13: 5A.

Darin, T., Dorsey, L., Taylor, M., \& Baker, L. (2003). Open letter to Prill Mecham, Re: Trappers Point Bottleneck. December 22, p. 4.

Dingle, H. (1996). Migration: The biology of life on the move. Oxford: Oxford University Press.

Einarsen, A. S. (1948). The pronghorn antelope and its management. Washington DC: The Wildlife Management Institute.

Ellickson, R. C. (1991). Order without law: How neighbors settle disputes. Cambridge: Harvard University Press.

Huntington, R. (2003). Migration route key to Teton antelope', Jackson Hole News \& Guide March 19: 16A.

Jalonick, M. C. (2005). Protect the corridor? Officials oppose designation, but parties say they'll work to help pronghorn. Casper Star Tribune August 8: A1.

Johnson, D. (1988). When antelope don't roam free. New York Times November 18: A16.

Lasswell, H. D. (1936). Politics: Who gets what, when, how. New York, NY: Whittlesey House, McGraw-Hill.

Lasswell, H. D. (1971). A pre-view of policy sciences. New York, NY: American Elsevier.

Lasswell, H. D., \& Kaplan, A. (1950). Power and society: A framework for political inquiry. New Haven, CT: Yale University Press.

Lasswell, H. D., \& McDougal, M. S. (1992). Jurisprudence for a free society: Studies in law, science, and policy. New Haven, CT and Dordrecht, The Netherlands: New Haven Press and Martinus Nijho.

Loftholm, N. \& McGuire, K. (2006). Boom life. Denver Post July 2.

Lubinski, P. M. (2001). Estimating age and season of death of Pronghorn Antelope (Antilocapra Americana Ord) by means of tooth eruption and wear. International Journal of Osteoarchaelogy, 11, 218-230.

McDougal, M. S., Lasswell, H. D., \& Reisman, W. M. (1981). The World constitutive process of authorative decision. In M. S. McDougal, \& W. M. Reisman (Eds.), International law essays: A supplement to international law in contemporary practice (pp. 191-282). New York, NY: Foundation Press.

Miller, M. E., \& Saunders, P. H. (2000). The trapper's point site (48SU1006): Early archaic adaptations and pronghorn procurement in the Upper Green River basin. Wyoming', Plain's Anthropologist, 45, 39-52.

O’Gara, B. W., \& Janis, C. M. (2004). Scientific classification. In B. W. O'Gara \& C. M. Janis (Eds.), Pronghorn ecology and management (pp. 3-25). Boulder, CO: University Press of Colorado, Wildlife Management Institute.

Reisman, W. M. (1988). International incidents: Introduction to a new genre in the study of international law. In W. M. Riesman, \& A. R. Willard (Eds.), International incidents: The law that counts in world politics (pp. 3-24). Princeton, NY: Princeton University Press.

Robbins, J. (2004). For wildlife, migration is endangered too. New York Times March 9: F1.

Sawyer, H., \& Lindzey, F. (2000). Jackson Hole pronghorn study. Laramie, WY: Wyoming Cooperative Fish and Wildlife Research Unit.

Shaul, R. (2003). Greens using wildlife corridors to raise money. Pinedale Roundup October 9: A4.

Straley, J. (1966). Western and Northwestern Wyoming. Wyoming Wildlife, 30, 19-20.

Taylor, D., \& Clark, T. W. (2005). Management context: People, animals, and institutions. In T. W. Clark, M. B. Rutherford, \& D. Casey (Eds.), Coexisting with large carnivores: Lessons from Greater Yellowstone (pp. 28-67). Washington, D.C.: Island Press.

Thomas, E. (1966). The pronghorn antelope. Wyoming Wildlife, 30, 12-14.

Thomson, J. L., Schaub, T. S., Culver, N. W., \& Aengst, P. C. (2005). Wildlife at a crossroads: Energy development in Western Wyoming. Washington, D.C.: The Wilderness Society.

Weiss, J. A. (1989). The powers of problem definition: The case of government paperwork. Policy Sciences, $22,92-121$.

Williams, T. (2004). For a week's worth of gas, Mother Jones September/October: 66-73.

Wyoming Game and Fish Department. (2003). Annual report, Cheyenne, WY: Wyoming Game and Fish Department. 


\section{Occupations, affiliations, or residential locations of anonymous interviewees and date of interviews}

Anonymous Environmental Donor, June 15, 2005.

Anonymous Environmentalist, June 4, 2004.

Anonymous Grassroots Conservationist, June 15, 2004.

Anonymous Natural Gas Worker, July 28, 2004.

Anonymous Rancher from Daniel, WY, June 17, 2004.

Anonymous Representative of Grand Teton National Park, June 8, 2004 and August 14, 2004.

Anonymous Representative of Greater Yellowstone Coalition, June 12, 2004 and July 14, 2004.

Anonymous Representative of the Jackson Hole Conservation Alliance, June 21, 2004.

Anonymous Representative of Pinedale Planning and Zoning, July 15, 2004.

Anonymous Representative of Shell Oil, June 14, 2004.

Anonymous Representative A of the Sublette County Commission, June 1, 2004.

Anonymous Representative B of the Sublette County Commission, June 1, 2004.

Anonymous Representative of the Upper Green Cattlemen Association, June 17, 2005.

Anonymous Representative of a Wildlife Conservation Organization, June 21, 2004 and June 28, 2004.

Anonymous Representative A of the Wyoming Game and Fish Department, June 8, 2004.

Anonymous Representative B of the Wyoming Game and Fish Department, June 11, 2004.

Anonymous Resident from Pinedale, WY, June 14, 2004.

Anonymous State Representative, June 14, 2004. 